\title{
Differences in Body Composition of Football Players of Two Top Football Clubs
}

\author{
Jovan Gardasevic ${ }^{1}$, Dusko Bjelica ${ }^{1}$, Ivan Vasiljevic ${ }^{1}$, Marin Corluka² \\ 'University of Montenegro, Faculty for Sport and Physical Education, Niksic, Montenegro, ${ }^{2}$ University of Mostar, Faculty of Mathematics and Science \\ Education, Mostar, Bosnia and Herzegovina
}

\begin{abstract}
The aim of this research was to determine the differences among the football players of the football club in Bosnia and Herzegovina, CSC Zrinjski Mostar and the football players of the football club in Montenegro FC Sutjeska Niksic, in the anthropometric characteristics and body composition. A sample of 51 subjects was divided into two sub-samples. The first sub-sample of the subjects consisted of 28 football players of CSC Zrinjski Mostar of the average age 24.36 \pm 4.14 , the champions of the Bosnia and Herzegovina in the season 2016/17, while the other sub-sample consisted of 23 players of FC Sutjeska Niksic of the average age of 21.69 \pm 4.30 , the winner of the Cup of Montenegro in the season 2016/17. Football players were tested immediately after the end of the competition season 2016/17. Anthropometric characteristics in the body composition were evaluated by a battery of 10 variables: body height, body weight, waist circumference, triceps skinfold, biceps skinfold, skinfold of the back, abdominal skinfold, body mass index, fat percentage and muscle mass. The significance of the differences between the football players of the top two football clubs in the Anthropometric characteristics and variables for assessing body composition was determined by a t-test for independent samples. It was found that the football players of the two mentioned clubs have statistically significant differences by the three variables that estimate the waist circumference, triceps skinfold and skinfold of the back, in a favor of FC Sutjeska Niksic.
\end{abstract}

Key words: Anthropometric Characteristics, Body Composition, Football Players

\section{Introduction}

A football game is said to be the most important secondary thing in the world, it gathers huge masses at stadiums and in front of TVs (Gardašević, 2010; Gardašević, Bjelica, Popović, \& Milašinović, 2016). It is a highly dynamic and fast team game which, with its richness of movement, falls under category of polystructural sports games (Bjelica, 2005; Gardašević i Goranović, 2011; Gardašević i Bjelica, 2013; Gardaševic \& Bjelica, 2014a; Gardasevic i Bjelica, 2014b). Football is a sport that is characterized by numerous and various complex and dynamic kinesiological activities which are then characterized by either cyclical (Gardašević, Vasiljević i Bojanić, 2015; Bjelica, Popović, \& Gardašević, 2016a; Bjelica, Popović i Gardašević, 2016b; Sermaxhaj, Popovic, Bjelica, Gardasevic, \& Arifi, 2017; Gardasevic, Bjelica, \& Vasiljevic, 2017a; Gardasevic, Bjelica, \& Vasiljevic, 2017b) or acyclical movement (Gardasevic, 2015; Gardašević i sar., 2015; Gardašević, Bjelica i Vasiljević, 2016a; Gardašević, Bjelica i Vasiljević, 2016b; Gardasevic, Bjelica, Milasinovic i Vasiljevic, 2016; Gardaševic i Vasiljević, 2016; Gardasevic, Popovic, \& Bjelica, 2016). In football, top score can be achieved only under conditions of well-programmed training process (Gardašević, Bjelica i Popović, 2015). High quality management of the training process depends on the knowing of the structure of certain anthropological capabilities and player's characteristics, as well as their development (Bjelica i Popović, 2012; Bjelica, 2013). Various researches are to be done in order to establish certain principles and norms for the transformational processes of the anthropological characteristics important for football (Gardašević, Bjelica, Georgiev, \& Popović, 2012); with

\section{Montenegro}

Sport

\section{Correspondence:}

\section{J. Gardasevic}

University of Montenegro, Faculty for Sport and Physical Education, Narodne omladine bb, 81400 Niksic, Montenegro

E-mail: jovan@ucg.ac.me 
anthropometric characteristics and body composition among them as expected. Findings regarding anthropometric characteristics and body composition are of crucial importance for complex sports games such as football. The anthropometric space is defined by the longitudinal dimension of the skeleton, the transversal dimensionality of the skeleton, the mass and volume of the body (Bjelica \& Fratrić, 2011). The purpose of knowing anthropometric characteristics is to improve skills in many sports (Carter \& Heath, 1990). The anthropometric status of top level athletes is relatively homogeneous, depending on the sport, and it can be defined as a model of athletic achievement (Mišigoj-Duraković, Matković, \& Medved, 1995). Research on anthropometric characteristics and body composition among athletes of different sports indicates that athletes of different sports have their own specific characteristics. Muscle mass improves performance in activities that require muscular strength and endurance, but also in those that require enviable aerobic ability (Ramadan \& Byrd, 1987; Green, 1992; Rico-Sanz, 1998).

Today, football is certainly the number one sport in the world for its view and popularity (Gardašević, Georgiev, \& Bjelica, 2012; Vasiljević, Gardašević, \& Bojanić, 2013; Gardasevic, Bjelica, Vasiljevic, Arifi, \& Sermaxhaj, 2019), and the same applies to Bosnia and Herzegovina and Montenegro (Bjelica, Gardasevic, Vasiljevic, Arifi, \& Sermaxhaj, 2019). The two clubs that are at the top of the Premier League of Bosnia and Herzegovina and of the First Montenegrin Telecom League, in the 2016/17 competitive season, they both have achieved a staggering success, CSC Zrinjski Mostar was the champion of Bosnia and Herzegovina and FC Sutjeska-Niksic was the winner of the Cup of Montenegro. Based on these two trophies that they have won at the end of the competition season, both clubs have acquired the right to play on the international football scene within the framework of UEFA's Champions League qualification and UEFA's Europa League qualification. It became as interesting for researchers to determine the models of anthropometric characteristics and body composition of the players who play for these clubs as to determine the differences among them.

The aim of this research was to determine anthropometric characteristics and body composition of elite football players, players of CSC Zrinjski Mostar who compete in the Telecom Premier League of Bosnia and Herzegovina and players of FC Sutjeska Niksic, who compete in the First Montenegrin Telecom League. Afterwhich, compare the variables between these football players and determine the possible differences between them.

\section{Method}

The data obtained in the study of anthropometric characteristics and body composition are checked and prepared for processing according to the set goal. Data bases are arranged according to the features and prepared for planned statistical processing. The results obtained by statistical analysis are presented in the tables and analyzed by the corresponding logical units. In general, the results of the research, through gradualness in the explanation of individual relationships, allow seeing differences in the observed anthropometric measures and body composition in accordance with the aim of the research, that is, they contribute to a clearer application of the obtained results in practice. In terms of time constraint, the research is of transversal character, and it consists of a one-off measurement of the corresponding anthropometric characteristics and body composition of top-level senior football players.

\section{Sample of subjects}

A sample of the subjects consists of a total of 51 top-level senior football players who performed in the Premier League of Bosnia and Herzegovina and the First Montenegrin Telecom League, divided into two sub-samples. The first one consists of 28 football players of CSC Zrinjski Mostar, the average age of 24.36 \pm 4.14 , Bosnia and Herzegovina's Championship winner in season 2016/17, and the second one that consists of 23 football players of FC Sutjeska Niksic of the average age $21.69 \pm 4.30$, the winner of the Cup of Montenegro in the season $2016 / 17$. The football players were tested immediately after the 2016/17 season ended.

\section{Sample of measures}

Anthropometric research has been carried out with respect to the basic rules and principles related to the selection of measuring instruments and measurement techniques standardized in accordance with the International Biological Program guidelines. For the purpose of this study, 7 anthropometric measures have been taken: body height, body weight, waist circumference, triceps skinfold, biceps skinfold, skinfold of the back and abdominal skinfold, and 3 body composition assessment variables: body mass index (BMI), fat percentage and muscle mass. Anthropometer, caliper, and measuring tape were used for anthropometric measurements. To evaluate the body composition, Tanita body fat scale - model BC-418MA, was used. The principle of this scale is based on indirect measurement of the body composition; a safe electrical signal is transmitted through the body via electrodes located in the standalone unit. The Tanita Scale, thanks to its athletics mode, enables athletes to closely monitor their body weight, health condition and form with all relevant parameters.

\section{Method of data processing}

The data obtained through the research are processed by descriptive and comparative statistical procedures. For each variable, central and dispersion parameters, as well as asymmetry and flattening measures are processed. Differences in anthropometric characteristics and the composition of the body of the football players of these two clubs were determined by using a discriminatory parametric procedure with t-test for small independent samples, with statistical significance of $\mathrm{p}<0.05$.

\section{Results}

In Tables 1 and 2, basic descriptive statistical parameters of anthropometric variables and body composition of the football players of the two clubs, where the values of central measurements and dispersion tendencies are calculated, are shown: arithmetic mean (Mean), standard deviation (S.D.), variance, minimal (Min) i maximal (Max) values, coefficient of curvature (Skewness) and elongation (Kurtosis). First, the central and dispersion parameters of the variables were analyzed to evaluate the anthropometric characteristics and body composition of the football players of CSC Zrinjski Mostar (Table 1). 
Table 1. Central and dispersion parameters of variables for assessment of anthropometric characteristics and body composition of football players of CSC Zrinjski Mostar ( $N=28)$

\begin{tabular}{lcccccc}
\hline Variables & Min & Max & Mean \pm S.D. & Variance & Skewness & Kurtosis \\
\hline Body height & 170.8 & 193.0 & $182.59 \pm 4.82$ & 23.27 & -.07 & .25 \\
Body weight & 70.0 & 90.5 & $78.85 \pm 5.80$ & 33.68 & .13 & -.92 \\
Waist circumference & 77.0 & 98.0 & $86.39 \pm 4.35$ & 18.91 & .34 & .95 \\
Triceps skinfold & 4.6 & 13.0 & $7.59 \pm 2.09$ & 4.39 & .88 & .63 \\
Biceps skinfold & 3.3 & 6.2 & $4.33 \pm .74$ & .55 & 1.07 & .59 \\
Skinfold of the back & 3.7 & 13.8 & $9.23 \pm 2.18$ & 4.74 & .31 & .92 \\
Abdominal skinfold & 4.0 & 15.0 & $8.02 \pm 2.77$ & 7.66 & .89 & .36 \\
BMl-body mass index & 21.4 & 26.1 & $23.63 \pm 1.14$ & 1.30 & .16 & -.47 \\
Fat percentage & 3.9 & 14.6 & $8.79 \pm 3.18$ & 10.14 & -.05 & -.88 \\
Muscle mass & 35.5 & 46.9 & $40.67 \pm 2.67$ & 7.12 & .05 & -.03 \\
\hline
\end{tabular}

Based on the central and dispersion parameters, the values of the skewness and the kurtosis, it can be noted that all the variables are placed within the normal distribution boundaries. Generally, according to all statistical parameters, it can be concluded that here we have some top football players; that there is a normal distribution in all variables and that the results that prevail are superior to the arithmetic mean, which is not statistically significant because it is to be expected that regarding football players of a professional football club, there is no too large a span between the results of analyzed variables. Table 2 showed the central and dispersion parameters of the variables were analyzed to evaluate the anthropometric characteristics and body composition of the football players of FC Sutjeska Niksic.

Table 2. Central and dispersion parameters of variables for assessment of anthropometric characteristics and body composition of football players of FC Sutjeska Niksic ( $\mathrm{N}=23)$

\begin{tabular}{lcccccc}
\hline Variables & Min & Max & Mean \pm Std.D. & Variance & Skewness & Kurtosis \\
\hline Body height & 166.0 & 195.0 & $182.99 \pm 6.77$ & 45.83 & -.55 & .61 \\
Body weight & 68.0 & 91.7 & $78.33 \pm 7.71$ & 59.43 & .48 & -1.16 \\
Waist circumference & 76.0 & 90.0 & $83.00 \pm 3.82$ & 14.64 & .28 & -.54 \\
Triceps skinfold & 3.4 & 9.8 & $6.46 \pm 1.66$ & 2.77 & .26 & -.22 \\
Biceps skinfold & 3.1 & 7.7 & $4.52 \pm 1.22$ & 1.49 & 1.12 & .94 \\
Skinfold of the back & 6.4 & 11.8 & $8.13 \pm 1.42$ & 2.01 & 1.10 & 1.15 \\
Abdominal skinfold & 5.4 & 14.0 & $8.25 \pm 2.38$ & 5.65 & .85 & .03 \\
BMl-body mass index & 21.7 & 25.8 & $23.36 \pm 1.41$ & 1.99 & .43 & -1.33 \\
Fat percentage & 2.6 & 13.6 & $8.66 \pm 2.92$ & 8.53 & -.38 & -.51 \\
Muscle mass & 34.1 & 46.8 & $40.56 \pm 3.81$ & 14.51 & -.03 & -1.19 \\
\hline
\end{tabular}

Based on the central and dispersion parameters, the values of skewness and kurtosis of the football players of FC Sutjeska-Niksic, it can be stated that all the variables are within the normal distribution boundaries and that the values are very similar to those of the football players of CSC Zrinjski Mostar. It can also be stated that the football players of FC Sutjeska-Niksic are younger on average. It can also be concluded that almost all variables of quantitative value are better with football players of FC Sutjeska-Niksic. However, a compara- tive statistical procedure, t-test (Table 3 ), will show whether it is statistically significant. By the value of the skewness, it can be noticed that in the variables of the biceps skinfold and skinfold of the back, there was a slight inclination on the side of the lower results, which is good because subcutaneous fat is a disrupting factor for professional athletes. In order to determine whether there are statistically significant differences in the analyzed variables in the top football players of these two clubs, the statistical procedure t-test (Table 3) was applied.

Table 3. T-test values between the arithmetic mean of variables for the evaluation of anthropometric characteristics and body composition of football players of CSC Zrinjski Mostar ( $\mathrm{N}=28)$ and FC Sutjeska Niksic $(\mathrm{N}=23)$

\begin{tabular}{lccccc}
\hline Variables & Club & Mean \pm S. D. & Mean Difference & t-test & Sig. \\
\hline Body Height & CSC Zrinjski & $182.59 \pm 4.82$ & -.3984 & -.245 & .807 \\
& FC Sutjeska & $182.99 \pm 6.77$ & & & \\
Body Weight & CSC Zrinjski & $78.85 \pm 5.80$ & .5239 & .277 & .783 \\
Waist Circumference & FC Sutjeska & $78.33 \pm 7.71$ & & & \\
& CSC Zrinjski & $86.39 \pm 4.35$ & 3.3929 & 2.925 & .005 \\
Triceps Skinfold & FC Sutjeska & $83.00 \pm 3.82$ & & & \\
& CSC Zrinjski & $7.59 \pm 2.09$ & 1.1241 & 2.087 & .042 \\
\hline
\end{tabular}


(continued from previous page)

\begin{tabular}{lccccc}
\hline Variables & Club & Mean \pm S. D. & Mean Difference & t-test & Sig. \\
\hline Biceps Skinfold & CSC Zrinjski & $4.33 \pm .74$ & -.1932 & -.695 & .490 \\
& FC Sutjeska & $4.52 \pm 1.22$ & & & \\
Skinfold of the Back & CSC Zrinjski & $9.23 \pm 2.18$ & 1.1017 & 2.088 & .042 \\
& FC Sutjeska & $8.13 \pm 1.42$ & & & \\
Abdominal Skinfold & CSC Zrinjski & $8.02 \pm 2.77$ & -.2300 & -.314 & .755 \\
& FC Sutjeska & $8.25 \pm 2.38$ & & .749 & .458 \\
BMI-Body Mass Index & CSC Zrinjski & $23.63 \pm 1.14$ & .2677 & .780 \\
Fat Percentage & FC Sutjeska & $23.36 \pm 1.41$ & & .150 & .882 \\
Muscle Mass & CSC Zrinjski & $8.79 \pm 3.18$ & .1292 & .113 & .911 \\
\hline
\end{tabular}

Based on the obtained values of t-test results, it was found that the football players of the two mentioned clubs have statistically significant differences by the three variables that estimate the the waist circumference, triceps skinfold and skinfold of the back, in a favor of FC Sutjeska-Niksic.

\section{Discussion}

The aim of this study was to determine the difference in the anthropometric characteristics and body composition of the top football players of the champions' football club in Bosnia and Herzegovina, CSC Zrinjski Mostar and the top football players of the winner football club in Montenegro FC Sutjeska Niksic. A sample of 51 respondents was divided into two sub-samples. The first sub-sample consisted of the 28 football players of CSC Zrinjski Mostar of 24.36 44.14 age on average, who were a statistically significant older than the 23 football players of FC Sutjeska Niksic, who made the second sub-sample of $21.69 \pm 4.30$ age on average. The results were obtained by using a battery of 10 tests in the area of anthropometric characteristics and body composition. By looking into the basic descriptive statistical parameters, it can be concluded that we have examined professional sportsmen indeed. It can be noticed that the football players of both clubs are of the approximately similar mean values of the variables analyzed, which is not surprising because these are the top two football clubs in Bosnia and Herzegovina and Montenegro, a state where there are also a great concentration of good football players. The t-test results showed that the football players of the two mentioned clubs have statistically significant differences by the three variables that estimate the waist circumference, triceps skinfold and skinfold of the back, in a favor of FC Sutjeska Niksic. The first variable in which a statistically significant difference has been found is a variable that estimates waist circumference, where the football players of CSC Zrinjski Mostar also have a statistically higher value than the football players of FC Sutjeska Niksic. Also, at the variables of triceps skinfold and skinfold of the back, football players of CSC Zrinjski Mostar have shown statistically better values because a smaller number means a better result when the disrupting factor of subcutaneous fat on playing football is taken into account. Very similar characteristics of football players were obtained in the region, which shows that football players have similar the anthropometric characteristics and body composition in the whole region (Gardasevic, Bjelica, Popovic, Vasiljevic, \& Milosevic, 2018; Bjelica, Gardasevic, \& Vasiljevic, 2018; Corluka \& Vasiljevic, 2018; Bjelica, \& Gar- dasevic, 2019; Gardasevic, Bjelica, \& Vasiljevic, 2019; Bjelica, Gardasevic, Vasiljevic, Jeleskovic, \& Covic, 2019).

For other variables, some values are better for football players of CSC Zrinjski Mostar and some for football players of FC Sutjeska Niksic, although, insignificantly for statistics, which indicates that these football players have very similar anthropometric parameters and body composition, which is again, not surprising, considering that these two football clubs are the best in their countries in the 2016/17 competitive season. The values obtained in this research can be useful for coaches of these football clubs for making a comparison of their football players with others and formulate their work in a way that enables reduction of those parameters that are not good, and raise those that are good to a higher level. That will surely make their football players even better and more successful. Also, both clubs should turn to other researches and check the functional-motoric status, psychological preparation as well as tactical training of their football players and analyze whether there is room for their improvement. The results obtained in this research can serve as model parameters for the estimated variables for football players of all other football clubs in Bosnia and Herzegovina and Montenegro, because the football players that have been analyzed here, were among the best and the most successful football players in those two countries at the end of the competitive season 2016/17.

\section{Acknowledgements}

There are no acknowledgements.

\section{Conflict of Interest}

The authors declare that there are no conflicts of interest.

Received: 30 July 2019 | Accepted: 18 August 2019 | Published: 11 October 2019

\section{References}

Bjelica, D. (2005). Sistematizacija sportskih disciplina i sportski trening. Podgorica: Crnogorska sportska akademija.

Bjelica, D. (2013). Teorija sportskog treninga. Podgorica: Univerzitet Crne Gore. Bjelica, D., \& Fratrić, F. (2011). Sportski trening: teorija, metodika i dijagnostika. Nikšić: Fakultet za sport i fizičko vaspitanje.

Bjelica, D., i Popović, S. (2012). Fudbal-teorija, tehnika i taktika. Podgorica: Crnogorska sportska akademija.

Bjelica, D., Popović, S., i Gardašević, J. (2016a). Modeli fizičke pripreme vrhunskih sportaša i doziranje opterećenja. U Zborniku radova 14. godišnje međunarodne konferencije "Kondicijska priprema sportaša" (185-189), Zagreb: Udruga kondicijskih trenera Hrvatske.

Bjelica, D., Popović, S., i Gardašević, J. (2016b). Opći principi planiranja i programiranja fizičkih priprema sportaša. U Zborniku radova 14 . godišnje međunarodne konferencije "Kondicijska priprema sportaša" (190-192), Zagreb: Udruga kondicijskih trenera Hrvatske. 
Bjelica, D., Gardasevic, J., \& Vasiljevic, I. (2018). Differences in the Anthropometriccharacteristics and body composition of soccer players FC Sutjeska and FC Mladost in Montenegro. Journal of Anthropology of Sport and Physical Education, 2(2), 31-35. doi: 10.26773/jaspe.180406

Bjelica, D., \& Gardasevic, J. (2019). Body composition and anthropometric measures of soccer players, champions of Montenegro and Bosnia and Herzegovina. In Book of Abstracts of the 16th Annual Scientific Conference of Montenegrin Sports Academy "Sport, Physical Activity and Health: Contemporary Perspectives" (73-74), Podgorica: Montenegrin Sports Academy.

Bjelica, D., Gardasevic, J., Vasiljevic, I., Arifi, F., \& Sermaxhaj, S. (2019). Anthropometric measures and body composition of soccer players of Montenegro and Montenegro. Journal of Anthropology of Sport and Physical Education, 3(2), 29-34. doi: 10.26773/jaspe.190406

Bjelica, D., Gardasevic, J., Vasiljevic, I., Jeleskovic, E., \& Covic, N. (2019). Body Composition and Morphological Characteristics of Soccer Players in Bosnia and Herzegovina. Kinesiologia Slovenica, 25(1), 5-13.

Carter, J.E.L., \& Heath, B.H. (1990). Somatotyping-Development and application Cambridge, United Kingdom: Cambridge University Press.

Corluka, M., \& Vasiljevic, I. (2018). Differences in the Anthropometriccharacteristics and body composition of soccer players in Montenegro. Journa of Anthropology of Sport and Physical Education, 2(1), 3-7. doi: 10.26773/ jaspe. 180101

Gardašević, J. (2010). Efekti programiranog rada u pripremnom periodu na transformaciju bazično-motoričkih i situaciono-motoričkih sposobnost kod fudbalera kadetskog uzrasta. Neobjavljena magistarska teza. Nikšić: Fakultet za sport i fizičko vaspitanje.

Gardašević, J., i Goranović, K. (2011). Efekti programiranog rada u pripremnom periodu na transformaciju eksplozivne snage kod fudbalera kadeta. Sport Mont, 9(28-30), 55-62.

Gardašević, J., Georgiev, G., \& Bjelica, D. (2012). Qualitative changes of basic motor abilities after completing a six-week training programme. Acta Kinesiologica, 6(1), 70-74.

Gardašević, J., Bjelica, D., Georgiev, G., \& Popović, S. (2012). Transformation of situational motor abilities with soccer players-cadets. In Proceeding book, XVI International Scientific Congress "Olympic Sports and Sport for All" \& VI International Scientific Congress „Sport, Stress, Adaptation" (373-377), Sofia: National Sports Academy "Vassil Levski".

Gardašević, J., i Bjelica, D. (2013). Efekti programiranog trenažnog rada u trajanju od šest nedjelja na transformaciju fleksibilnosti kod fudbalera kadetskog uzrasta. Sport Mont, 11(37-39), 212-217.

Gardaševic, J., \& Bjelica, D. (2014a). The effects of the training in the preparation period on the dribbling speed with fifteen years old soccer players. In Book of Abstracts of the 11th International Scientific Conference on Trans formation Process in Sport "Sport Performance" (22-23), Podgorica: Montenegrin Sports Academy.

Gardasevic, J., i Bjelica, D. (2014b). Efekti rada u pripremnom periodu na brzinu vođenja lopte petnaestogodišnjih fudbalera. Sport Mont, 12(40-42), 160-166.

Gardašević, J., Vasiljević, I., \& Bojanić, D. (2015). Six-week preparation period and its effects on coordination transformation with soccer players under 16. In Book of Abstracts 11th International Scientific Conference Manage ment, Sport, Olympism (36), Beograd: Fakultet za menadžment u sportu, Alfa univerzitet.

Gardasevic, J. (2015). The effects of the training in the preparation period on the agility transformation with cadet level soccer players. In Book of Abstracts of the 12th International Scientific Conference on Transformation Process in Sport "Sport Performance" (76-77), Podgorica: Montenegrin Sports Academy.

Gardašević, J., Vasiljević, I., Bojanić, D., Muratović, A., Ljubojević, M., Milašinović, R., \& Bubanja, M. (2015). Six-week Preparation Period and its Effects on Transformation Movement Speed with Soccer Players Under 16. In Book of Abstracts, International Scientific Conference "Effects of Physical Activity Application to Anthropological Status with Children, Youth and Adults" (148), Belgrade:University of Belgrade: Faculty of Sport and Physical Education.
Gardašević, J., Bjelica, D., i Popović S. (2015). Efekti programiranog rada tokom pripremnog perioda na transformaciju agilnosti kod fudbalera kadetskog uzrasta. Sport Mont, 13(43-45), 355-360.

Gardašević, J., Bjelica, D., \& Vasiljević, I. (2016a). Six-Week Preparation Period and its Effects on Transformation Movement Speed with Soccer Players Under 16. Sport Mont, 14(1), 13-16.

Gardašević, J., Bjelica, D. \& Vasiljević, I. (2016b). The Effects of the Training in the Preparation Period on the Repetitive Strength Transformation with Cadet Level Soccer Players. In Book of Abstracts of the 13th International Scientific Conference on Transformation Processes in Sport "Sport Performance" (43), Podgorica: Montenegrin Sports Academy.

Gardasevic, J., Bjelica, D., Milasinovic, R., \& Vasiljevic, I. (2016). The Effects of the Training in the Preparation Period on the Repetitive Strength Transformation with Cadet Level Soccer Players. Sport Mont, 14(2), 31-33.

Gardaševic, J. \& Vasiljević, I. (2016). Effects of Preparation Period on Endurance in U16 Soccer Players. In Book of Abstracts of the 4TH International Scientific Conference "Exercise and Quality of Life" (108), Novi Sad: University of Novi Sad, Faculty of Sport and Physical Education.

Gardašević, J., Bjelica, D., Popović, S., \& Milašinović, R. (2016). Preparation Period and its Effects on the Speed of Ball Leading at Players U16. In Book of Summaries of 11th FIEP European Congress "Anthropological Aspects of Sport, Physical Education and Recreation" (30-31), Banjaluka: University of Banjaluka, Faculty of Physical Education and Sport.

Gardasevic, J., Popovic, S., \& Bjelica, D. (2016). After preparation period ball shooting accuracy at players U15. In Abstract Book of the 8th Conference for Youth Sport (88), Ljubljana: University of Ljubljana, Faculty of Sport.

Gardasevic, J., Bjelica, D., \& Vasiljevic, I. (2017a). The strength of kicking the ball after preparation period with U15 soccer players. In Book of Abstracts of the 14th International Scientific Conference on Transformation Processes in Sport "Sport Performance" (65-66), Podgorica: Montenegrin Sports Academy.

Gardasevic, J., Bjelica, D., \& Vasiljevic, I. (2017b). The Strength of Kicking the Ball after Preparation Period with U15 Soccer Players. Sport Mont, 15(2), 39-42.

Gardasevic, J., Bjelica, D., Popovic, S., Vasiljevic, I., \& Milosevic, Z. (2018). Differences in the Anthropometriccharacteristics and body composition of soccer players FC Buducnost and FC Mladost in Montenegro. Journal of Anthropology of Sport and Physical Education, 2(1), 51-55. doi: 10.26773/ jaspe.180109

Gardasevic, J., Bjelica, D., Vasiljevic, I., Arifi, F., \& Sermaxhaj, S. (2019). Differences in anthropometric measures of soccerers, cup winners of Montenegro and Montenegro. Journal of Anthropology of Sport and Physical Education, 3(1), 23-27. doi: 10.26773/jaspe.190105

Gardasevic, J., Bjelica, D., \& Vasiljevic, I. (2019). Body composition and anthropometric measures of soccer players, champions of Bosnia and Herzegovina and Montenegro. In Book of Abstracts of the 16th Annual Scientific Conference of Montenegrin Sports Academy "Sport, Physical Activity and Health: Contemporary Perspectives" (74-75), Podgorica: Montenegrin Sports Academy.

Green, S. (1992). Anthropometric and physiological characteristics of south Australian soccer players. Australian Journal of Science and Medicine in Sport, 24, 3-7.

Mišigoj-Duraković, M., Matković, B., \& Medved, R. (1995). Morfološka antropometrija u športu. Anthropometricanthropometry in sports. Zagreb, Croatia: Fakultet za fizičku kulturu.

Ramadan, J., \& Byrd, R. (1987). Physical characteristics of elite soccer players. Journal of Sports Medicine and Physical Fitness, 27, 424-428.

Rico-Sanz, J. (1998). Body composition and nutritional assessments in soccer. International Journal of Sport Nutrition, 8, 113-123.

Sermaxhaj, S., Popovic, S., Bjelica, D., Gardasevic, J., \& Arifi, F. (2017). Effect of recuperation with static stretching in isokinetic force of young soccer players. Journal of Physical Education and Sport, 17(3), 1948-1953. doi: 10.7752/jpes.2017.03191

Vasiljević, I., Gardašević, J., i Bojanić, D. (2013). Uporedna analiza motoričkog prostora između aktivnih fudbalera kadetskog uzrasta i učenika srednje škole. U Zborniku naučnih i stručnih radova VI međunarodni simpozijum "Sport i zdravlje" (212-215), Tuzla: Fakultet za tjelesni odgoj i sport. 